\title{
STUDI MODEL BENCHMARK MCNP6 DALAM PERHITUNGAN REAKTIVITAS BATANG KENDALI HTR-10
}

\section{STUDY ON MCNP6 BENCHMARK MODEL IN THE CALCULATION OF HTR-10 CONTROL ROD REACTIVITY}

\author{
Zuhair $^{1}$, Suwoto ${ }^{1}$, Putranto Ilham Yazid ${ }^{2}$, Jupiter S. Pane ${ }^{1}$ \\ ${ }_{1}^{1}$ Pusat Teknologi dan Keselamatan Reaktor Nuklir - BATAN \\ Kawasan Puspiptek, Gedung No. 80, Serpong, Tangerang Selatan 15310 \\ Tel. (021)756-0912, Fax. (021)756-0913 \\ 2Pusat Sains \& Teknologi Nuklir Terapan - BATAN \\ JI. Taman Sari No. 71, Bandung 40132 \\ Tel. (022)250-3997/98, 250-4898, Fax. (022)250-4081 \\ E-mail: zuhair@batan.go.id
}

Diterima: 11 Juli 2016, diterima dalam bentuk perbaikan: 27 September 2016, disetujui: 26 Oktober 2016

\begin{abstract}
ABSTRAK
STUDI MODEL BENCHMARK MCNP6 DALAM PERHITUNGAN REAKTIVITAS BATANG KENDALI HTR10. Dalam operasi reaktor nuklir, sistem batang kendali memainkan peranan yang sangat penting karena didesain untuk mengendalikan reaktivitas teras dan memadamkan reaktor. Nilai reaktivitas batang kendali harus diprediksi secara akurat melalui eksperimen dan perhitungan. Makalah ini mendiskusikan model Benchmark dalam perhitungan reaktivitas batang kendali reaktor HTR-10. Perhitungan dikerjakan dengan program transport Monte Carlo MCNP6 dan pustaka data nuklir energi kontinu ENDF/B-VII. Hasil perhitungan memperlihatkan prediksi MCNP6 memiliki kesesuaian yang cukup baik dengan pendekatan difusi maupun model Monte Carlo yang diestimasi China untuk reaktivitas sepuluh batang kendali fully in di teras penuh, masing-masing dengan bias perhitungan 2,28 \% dan 3,40\% (problema Benchmark B3.1) serta $6,44 \%$ dan 0,33\% (problema Benchmark B4.1). Simulasi MCNP6 memperlihatkan hasil yang kurang menguntungkan dalam kasus reaktivitas satu batang kendali fully in di teras penuh (problema Benchmark B3.2), namun sebaliknya mendemonstrasikan akurasinya yang paling tinggi di teras inisial dengan bias eksperimen 2,70 \% (problema Benchmark B4.2). Hasil-hasil ini menyimpulkan bahwa model MCNP6 yang digunakan dalam perhitungan reaktivitas batang kendali HTR-10 dapat diaplikasikan untuk analisis fisika teras reaktor pebble bed lainnya.
\end{abstract}

Kata kunci: model benchmark, reaktivitas batang kendali, HTR-10, MCNP6, ENDF/B-VII

\begin{abstract}
STUDY ON MCNP6 BENCHMARK MODEL IN THE CALCULATION OF HTR-10 CONTROL ROD REACTIVITY. In the operation of a nuclear reactor, the control rod system plays a very important role because it is designed to control the core reactivity and shutdown the reactor. The reactivity control rod worth has to be predicted accurately through experiments and calculations. This paper discusses the benchmark model in the calculation of control rod reactivity of HTR-10 reactor. The calculations were performed by Monte Carlo transport code MCNP6 and continuous energy nuclear data libraries ENDF/B-VII. The calculation results show that the MCNP6 prediction have a good agreement with those of diffusion approach and Monte Carlo model estimated by China for reactivity worth of the ten fully in control rods in full core, with calculational biases of $2.28 \%$ and $3.40 \%$ (Benchmark problems B3.1) as well as $6.44 \%$ and $0.33 \%$ (Benchmark problems B4.1), respectively. The MCNP6 simulation shows less favorable result in the case of the reactivity worth of one fully in control rod in full core (Benchmark problem B3.2), but otherwise it demonstrates the highest accuracy in initial core with experimental bias of $2.70 \%$ (Benchmark problem B4.2). These results conclude that the MCNP6 Benchmark model used in the calculation of HTR-10 control rod reactivity can be applied to analyze core physics of the other pebble bed reactors.
\end{abstract}

Keywords: benchmark model, control rod reactivity, HTR-10, MCNP6, ENDF/B-VII 
Jurnal Iptek Nuklir Ganendra

Ganendra Journal of Nuclear Science and Technology

Vol. 9, No. 2, Juli 2016: 95-103

\section{PENDAHULUAN}

Deaktor temperatur tinggi (high temperature reactor, HTR) merupakan salah satu jenis dari enam konsep Rreaktor Generasi IV yang menawarkan karakteristik performa yang menjanjikan. Konsep reaktor ini menghasilkan energi yang berkelanjutan, menawarkan peningkatan resistensi proliferasi, menjanjikan operasi burnup tinggi dan margin kegagalan bahan bakar yang besar dengan retensi produk fisi yang sangat baik melalui desain bahan bakar TRISO. Temperatur operasi yang sangat tinggi membuat konsep reaktor ini dapat mendukung aplikasi panas proses industri [1].

Sejauh ini terdapat dua konsep desain utama HTR, yaitu reaktor dengan elemen bakar tipe blok yang disebut HTR prismatik dan reaktor dengan bahan bakar bola (pebble) yang disebut HTR pebble bed. Reaktor uji temperatur tinggi (high temperature test reactor, HTTR) yang dioperasikan dan dikembangkan oleh Jepang adalah contoh HTR prismatik sedangkan HTR-10 adalah contoh HTR pebble bed yang dibangun dan dioperasikan di Institute of Nuclear Energy and Technology (INET), Universitas Tsinghua, Beijing, China [2].

Dalam operasi reaktor nuklir, sistem batang kendali memainkan peranan yang sangat penting karena didesain untuk mengendalikan reaktivitas teras dan memadamkan reaktor. Nilai reaktivitas batang kendali harus diprediksi secara akurat melalui eksperimen dan perhitungan menggunakan pendekatan transport dan difusi neutron serta model Monte Carlo. Memodelkan batang kendali reaktor pebble bed merupakan sebuah tantangan yang memerlukan penanganan khusus karena kompleksitas geometrinya yang ekstra rumit. Oleh karena itu, problema Benchmark fisika teras reaktor HTR-10 dalam Coordinated Research Program (CRP) yang diusulkan IAEA memasukkan perhitungan reaktivitas batang kendali untuk teras penuh (problema Benchmark B3) dan perhitungan reaktivitas batang kendali untuk teras inisial (problema Benchmark B4). Beberapa negara berpartisipasi dalam program ini untuk studi Benchmark code to code dan Benchmark experiment to code guna meningkatkan kepercayaan fisikawan reaktor dan ahli teknologi nuklir mereka dalam pengembangan model komputasi probabilistik maupun deterministik yang handal dan presisi.

Tujuan dari studi ini adalah membuat dan mendiskusikan model Benchmark MCNP6 untuk menyelesaikan perhitungan reaktivitas batang kendali reaktor HTR-10. Perhitungan dikerjakan dengan program transport Monte Carlo MCNP6 [3] dan pustaka data nuklir energi kontinu ENDF/B-VII [4]. Teknik Monte Carlo dipilih karena kapabilitasnya yang teruji dalam memodelkan geometri kompleks secara detail, tanpa homogenisasi maupun simplifikasi. Teknik Monte Carlo banyak digunakan dalam studi berbagai jenis sistem reaktor dan beberapa studi analisis kritikalitas HTR-10 [2, 5-8]. Studi ini juga akan mendiskusikan komparasi hasil perhitungan reaktivitas batang kendali dengan data eksperimen dan hasil komputasi analitik lainnya untuk melengkapi analisis model Benchmark MCNP6.

\section{DESKRIPSI TERAS HTR-10}

HTR-10 dibangun untuk menguji dan mengembangkan bahan bakar, memverifikasi fitur keselamatan reaktor pebble bed dan mendemonstrasikan produksi listrik yang dikombinasikan dengan ko-generasi panas proses serta untuk memberikan pengalaman desain, operasi dan konstruksi reaktor pebble bed [9]. Teras HTR10 memiliki diameter $180 \mathrm{~cm}$, tinggi rerata $197 \mathrm{~cm}$ dan dikelilingi oleh reflektor grafit dengan ketebalan radial 100 $\mathrm{cm}$ dan ketebalan aksial total $351 \mathrm{~cm}$. Sebanyak 17.000 bahan bakar pebble dengan pengkayaan U235 sebesar $17 \%$ menempati teras reaktor. HTR-10 dapat dioperasikan hingga burnup rerata teras $80.000 \mathrm{MWd} / \mathrm{tU}$ [10].

Dalam teras inisial, moderator pebble dari grafit murni berdiameter $3 \mathrm{~cm}$ ditempatkan terlebih dahulu di konus yang terletak di bagian bawah teras. Campuran bahan bakar pebble dan moderator pebble kemudian dimuatkan dari atas teras secara bertahap dengan rasio 57:43 hingga kritikalitas pertama dicapai. Campuran pebble dengan rasio yang sama dimuatkan lebih lanjut ke dalam teras agar reaktor dapat dioperasikan pada daya penuh. Teras penuh memiliki volume nominal $5 \mathrm{~m}^{3}$. Pendingin helium yang berasal dari dua puluh kanal melingkar di reflektor sisi memasuki teras reaktor mengikuti pola aliran dari atas ke bawah melalui sela-sela tumpukan pebble yang tersusun secara acak dengan fraksi packing 0,61. Parameter desain utama HTR-10 dapat dilihat dalam Tabel 1. 
Tabel 1. Parameter desain utama HTR-10 [10].

\begin{tabular}{lr}
\hline Parameter & \\
\hline Daya termal reaktor (MW) & 10 \\
Diameter / tinggi teras reaktor $(\mathrm{cm})$ & 180 / 197 \\
Tekanan pendingin primer (MPa) & 3,0 \\
Temperatur inlet / oulet pendingin rerata $\left({ }^{\circ} \mathrm{C}\right)$ & $250 / 700$ \\
Laju aliran massa pendingin (kg/s) & 4,3 \\
Tekanan uap outlet (MPa) & 4,0 \\
Temperatur inlet / outlet generator uap ( $\left.{ }^{\circ} \mathrm{C}\right)$ & $104 / 400$ \\
Laju aliran uap (ton/jam) & 12,5 \\
Jumlah bahan bakar pebble di teras setimbang & 27.000 \\
Moda pemuatan bahan bakar & Multi-pass \\
\hline
\end{tabular}

Bahan bakar pebble dengan diameter $6 \mathrm{~cm}$ dikomposisi oleh 8.335 partikel berlapis TRISO. Setiap partikel TRISO terdiri atas kernel $\mathrm{UO}_{2}$ dan empat lapisan coating. Coating 1: porous carbon buffer, didesain untuk menyediakan ruang bagi produk fisi berbentuk gas. Coating 2: inner pyrolitic carbon (iPyC), memiliki densitas rendah dan bertindak sebagai perintang difusi untuk produk fisi. Coating 3: silikon karbida (SiC), memiliki densitas tinggi dan menjadi tumpuan kekuatan partikel bahan bakar. Coating 4: outer pyrolitic carbon (oPyC), berfungsi sebagai pelindung lapisan $\mathrm{SiC}$ dan perintang difusi lebih lanjut.

Tabel 2. Karakteristik bahan bakar pebble HTR-10 [10].

\begin{tabular}{lr}
\hline Bahan bakar pebble & \\
\hline Diameter pebble $(\mathrm{cm})$ & 6,0 \\
Diameter zona bahan bakar $(\mathrm{cm})$ & 5,0 \\
Densitas grafit dalam matriks dan shell $\left(\mathrm{g} / \mathrm{cm}^{3}\right)$ & 1,73 \\
Massa uranium per pebble $(\mathrm{g})$ & 5,0 \\
Pengkayaan $\mathrm{U}^{235}(\%)$ & 17 \\
Impuritas boron alam ekuivalen dalam uranium $(\mathrm{ppm})$ & 4 \\
Impuritas boron alam ekuivalen dalam grafit $(\mathrm{ppm})$ & 1,3 \\
Fraksi packing pebble dalam teras & 0,61 \\
\hline Kernel & \\
\hline Radius kernel $(\mathrm{cm})$ & 0,025 \\
Densitas UO2 $\left(\mathrm{g} / \mathrm{cm}^{3}\right)$ & 10,4 \\
\hline Coating & $\mathrm{PyC} / \mathrm{PyC} / \mathrm{SiC} / \mathrm{PyC}$ \\
\hline Material lapisan coating (dimulai dari kernel) & $1,1 / 1,9 / 3,18 / 1,9$ \\
Ketebalan lapisan coating $\left(\mathrm{cm}^{3}\right)$ & $0,009 / 0,004 / 0,0035 / 0,004$ \\
Densitas lapisan coating $\left(\mathrm{g} / \mathrm{cm}^{3}\right)$ & \\
\hline
\end{tabular}

Table 3. Karakteristik moderator pebble HTR-10 [10].

\begin{tabular}{lc}
\hline Moderator pebble & 6,0 \\
\hline Diameter pebble $(\mathrm{cm})$ & 5,0 \\
Densitas grafit $\left(\mathrm{g} / \mathrm{cm}^{3}\right)$ & 1,3 \\
Impuritas boron alam ekuivalen dalam grafit $(\mathrm{ppm})$ & \\
\hline
\end{tabular}

Pola manajemen bahan bakar HTR-10 mengikuti skema multi-pass dengan sistem penanganan bahan bakar pneumatik pulsa yang dimanfaatkan untuk pemuatan kontinu dan pengeluaran bahan bakar. Burnup bahan bakar diukur secara individual dan jika belum mencapai target burnup yang diinginkan, bahan bakar pebble akan disirkulasi ulang secara pneumatik ke atas teras reaktor. Tabel 2 dan Tabel 3 masing-masing memperlihatkan karakteristik bahan bakar pebble dan moderator pebble sedangkan Gambar 1 mengilustrasikan skematik bahan bakar pebble. 
Jurnal Iptek Nuklir Ganendra

Ganendra Journal of Nuclear Science and Technology

Vol. 9, No. 2, Juli 2016: 95-103

Dalam HTR-10 terdapat sepuluh batang kendali yang diletakkan vertikal dan melingkar secara uniform di dalam kanal reflektor sisi. Sistem batang kendali ini didesain untuk bekerja pada temperatur tinggi, radiasi tinggi dan lingkungan helium. Sebagai penyerap neutron digunakan boron karbida $\left(\mathrm{B}_{4} \mathrm{C}\right)$ dengan densitas $1,7 \mathrm{~g} / \mathrm{cm}^{3}$ dan komposisi karbon: 20\%, boron-10: 15,84 \% dan boron-11: 64,16 \%. Setiap batang kendali berisi lima segmen cincin $\mathrm{B} 4 \mathrm{C}$ yang ditempatkan di daerah antara lengan stainless steel bagian dalam dan lengan stainless steel bagian luar yang dikoneksikan bersama oleh sendi logam. Diameter dalam dan luar cincin $\mathrm{B}_{4} \mathrm{C}$ masingmasing adalah $6,0 \mathrm{~cm}$ dan $10,5 \mathrm{~cm}$, sedangkan panjang setiap segmen cincin adalah $48,7 \mathrm{~cm}$. Diameter dalam / luar dari lengan stainless steel bagian dalam adalah $5,5 \mathrm{~cm} / 5,9 \mathrm{~cm}$ dan dari lengan stainless steel bagian luar adalah 10,6 cm / 11,0 cm. Panjang setiap sendi adalah 3,6 cm. Panjang dari ujung logam bawah dan atas masing-masing 4,5 cm dan 2,3 cm. Gambar 2 mengilustrasikan skematik batang kendali HTR-10 sedangkan spesifikasi teknisnya diperlihatkan dalam Tabel 4.

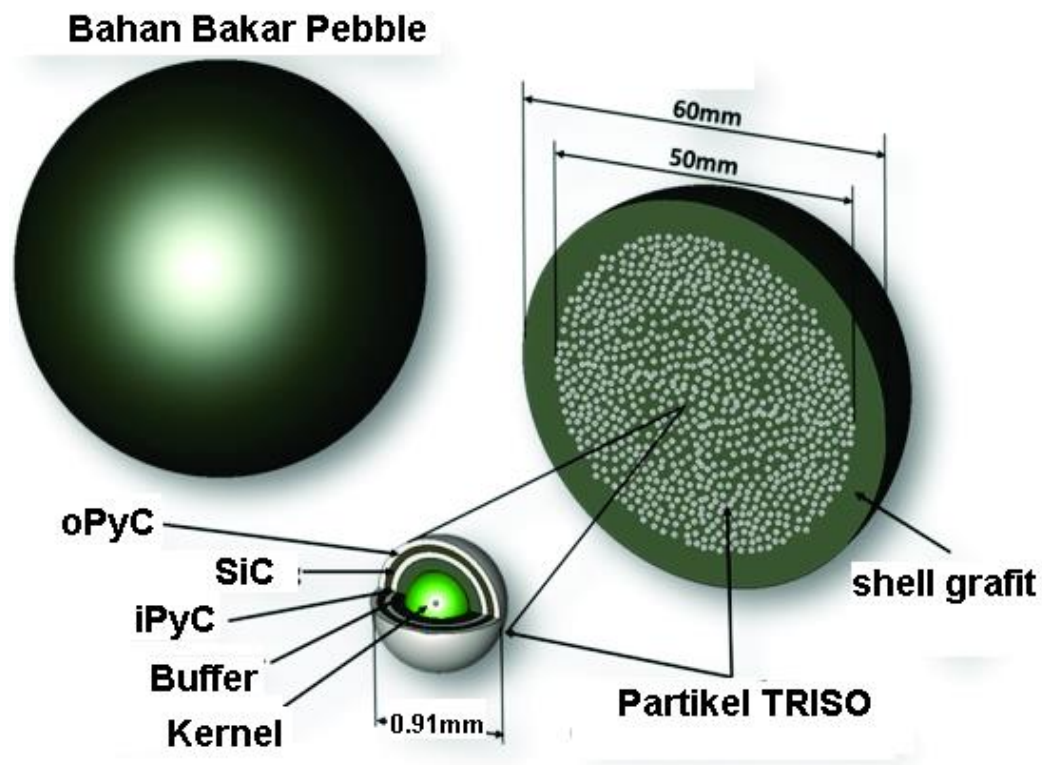

Gambar 1. Skematik bahan bakar pebble HTR-10.

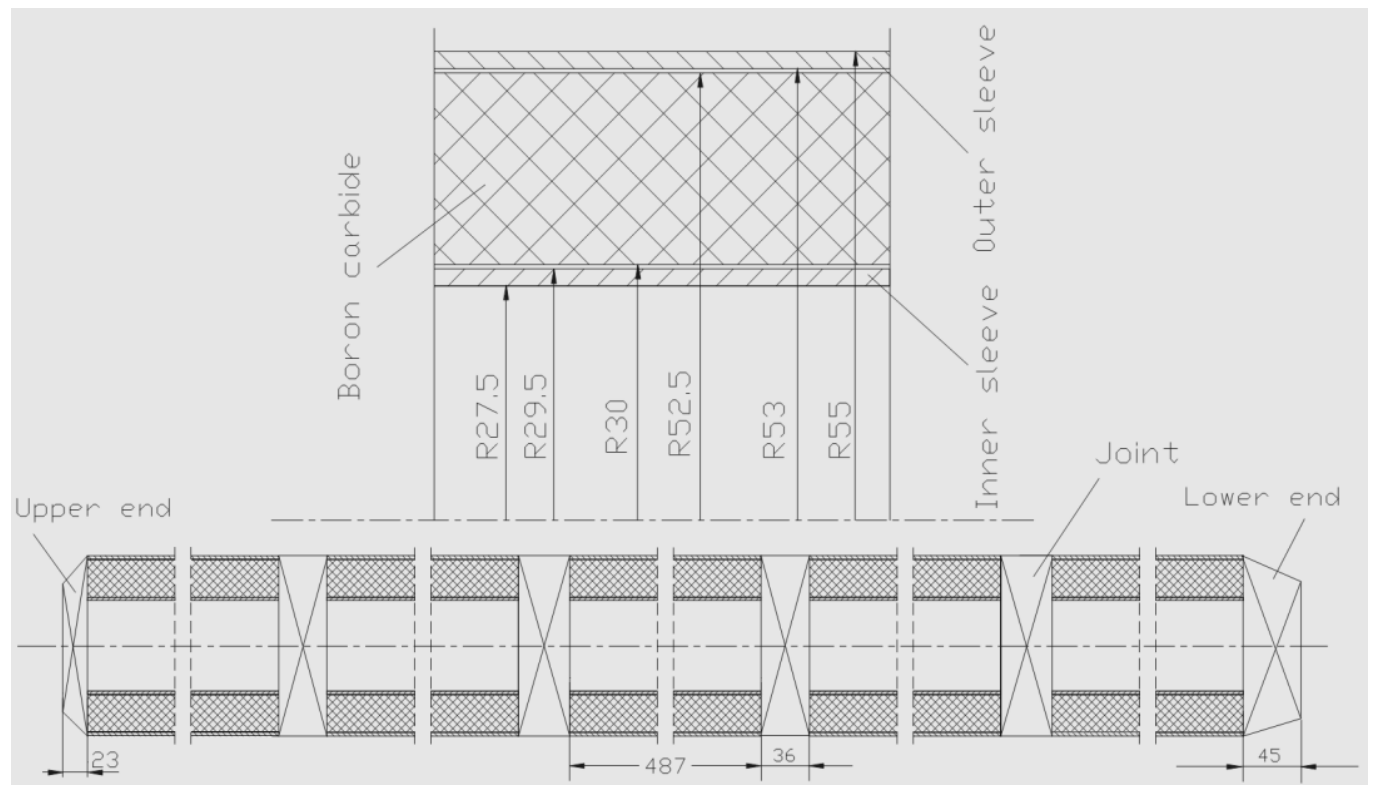

Gambar 2. Skematik batang kendali HTR-10 [10]. 
Tabel 4. Parameter desain sistem batang kendali HTR-10 [10].

\begin{tabular}{lr}
\hline Parameter & Nilai \\
\hline Ketinggian teras aktif rerata $(\mathrm{cm})$ & 197 \\
Jarak kanal batang kendali dari pusat teras reaktor $(\mathrm{cm})$ & 102,5 \\
Diameter kanal batang kendali $(\mathrm{cm})$ & 13 \\
Diameter dalam / luar penyerap $(\mathrm{cm})$ & $6,0 / 12,0$ \\
Material penyerap batang kendali & $\mathrm{B} 4 \mathrm{C}$ \\
Densitas penyerap batang kendali $\left(\mathrm{g} / \mathrm{cm}^{3}\right)$ & 1,7 \\
Panjang efektif total penyerap batang kendali $(\mathrm{cm})$ & 220 \\
Kecepatan insersi normal batang kendali $(\mathrm{cm} / \mathrm{s})$ & 1,0 \\
Waktu insersi darurat batang kendali $(\mathrm{s})$ & 8 \\
Panjang total batang kendali $(\mathrm{cm})$ & 275 \\
Medium & $\mathrm{He}$ \\
Tekanan $(\mathrm{MPa})$ & 3,0 \\
\hline
\end{tabular}

\section{MODEL BENCHMARK MCNP6}

Model Benchmark MCNP6 dibuat untuk menyelesaikan perhitungan reaktivitas batang kendali HTR-10 yang terdiri atas model bahan bakar pebble dan model teras reaktor. Pemodelan HTR-10 mempertimbangkan fitur heterogenitas ganda dari material stokastik untuk mendapatkan hasil perhitungan dengan akurasi yang tinggi. Fitur heterogenitas ganda dibagi ke dalam dua level: heterogenitas pebble yang tersusun secara acak dalam teras reaktor dan heterogenitas partikel TRISO yang terdispersi secara acak dalam bahan bakar pebble. Fitur ini sering ditinggalkan atau diabaikan dalam pendekatan deterministik karena pemodelannya yang sulit namun dalam perhitungan Monte Carlo kesulitan tersebut dapat ditangani dengan seksama.

\section{Model bahan bakar pebble}

Model bahan bakar pebble diawali dengan memodelkan partikel TRISO dalam kisi satuan kubik sederhana (simple cubic, SC). Partikel TRISO ditempatkan di pusat kisi dengan matriks grafit berada di sekeliling partikel. Densitas dan dimensi TRISO adalah eksak. Kisi satuan ini kemudian diekspansi ke dalam bahan bakar pebble dengan struktur repetitif hingga 8.335 partikel TRISO sepenuhnya berada di dalam zona bahan bakar. Shell grafit setebal $0,5 \mathrm{~cm}$ yang mengelilingi zona bahan bakar dimodelkan untuk melengkapi model bahan bakar pebble.

Pitch kisi sebesar $0,198789 \mathrm{~cm}$ yang digunakan dalam perhitungan didapatkan dari hubungan radius zona bahan bakar dan jumlah partikel TRISO dalam pebble. Dalam model ini, tidak dilakukan koreksi terhadap kontribusi partikel yang terpotong di permukaan sferis zona bahan bakar karena hasil perhitungan tanpa koreksi dan dengan koreksi sangat dekat satu dengan lainnya dan tidak memperlihatkan perbedaan yang signifikan. Lagi pula efek batas pebble pada umumnya dapat diabaikan untuk perhitungan teras pebble bed dan hanya penting untuk perhitungan sel [1].

\section{Model teras reaktor}

Model teras reaktor HTR-10 diawali dengan memodelkan pebble dalam kisi satuan body-centered cubic (BCC). Struktur kisi ini dapat menggambarkan 2 pebble yang terdiri atas 1 bahan bakar pebble di pusat kisi dan 8 $\times 1 / 8$ moderator pebble di delapan sudut kisi. Pendingin helium dalam kisi dimodelkan berada di luar kedua pebble. Densitas moderator pebble adalah eksak sedangkan dimensinya direduksi dari radius $3 \mathrm{~cm}$ ke 2,730984 $\mathrm{cm}$ untuk menjamin rasio bahan bakar pebble dan moderator pebble dalam teras tetap 57:43. Pitch kisi BCC disesuaikan menjadi $6,878190 \mathrm{~cm}$ untuk mempertahankan fraksi packing pebble tidak berubah dari 0,61. Kisi satuan ini kemudian diekspansi untuk mengisi volume teras dengan struktur repetitif. Zona eksklusif dari helium dimodelkan untuk mengkompensasi kontribusi pebble parsial. Pebble parsial didefinisikan sebagai bahan bakar pebble dan moderator pebble yang terpotong di permukaan radial teras. 
Jurnal Iptek Nuklir Ganendra

Ganendra Journal of Nuclear Science and Technology

Vol. 9, No. 2, Juli 2016: 95-103

Representasi eksak dari komponen reaktor lainnya seperti reflektor grafit dengan kanal untuk pendingin, batang kendali dan bola penyerap kecil (small absorber ball) dimodelkan secara eksplisit dan detail termasuk konus di bawah teras reaktor yang ditempati moderator pebble dengan fraksi packing 0,61 . Kompleksitas sepuluh batang kendali yang memerlukan penanganan ekstra sulit, juga dimodelkan secara eksplisit dan terperinci. Beberapa riset sebelumnya [11-12] yang menguraikan pemodelan reaktor pebble bed dan HTR-10 secara panjang lebar dapat diacu untuk lebih memahami pemodelan ini. Gambar 3 mengilustrasikan model MCNP6 untuk teras HTR-10 dalam problema Benchmark reaktivitas batang kendali.
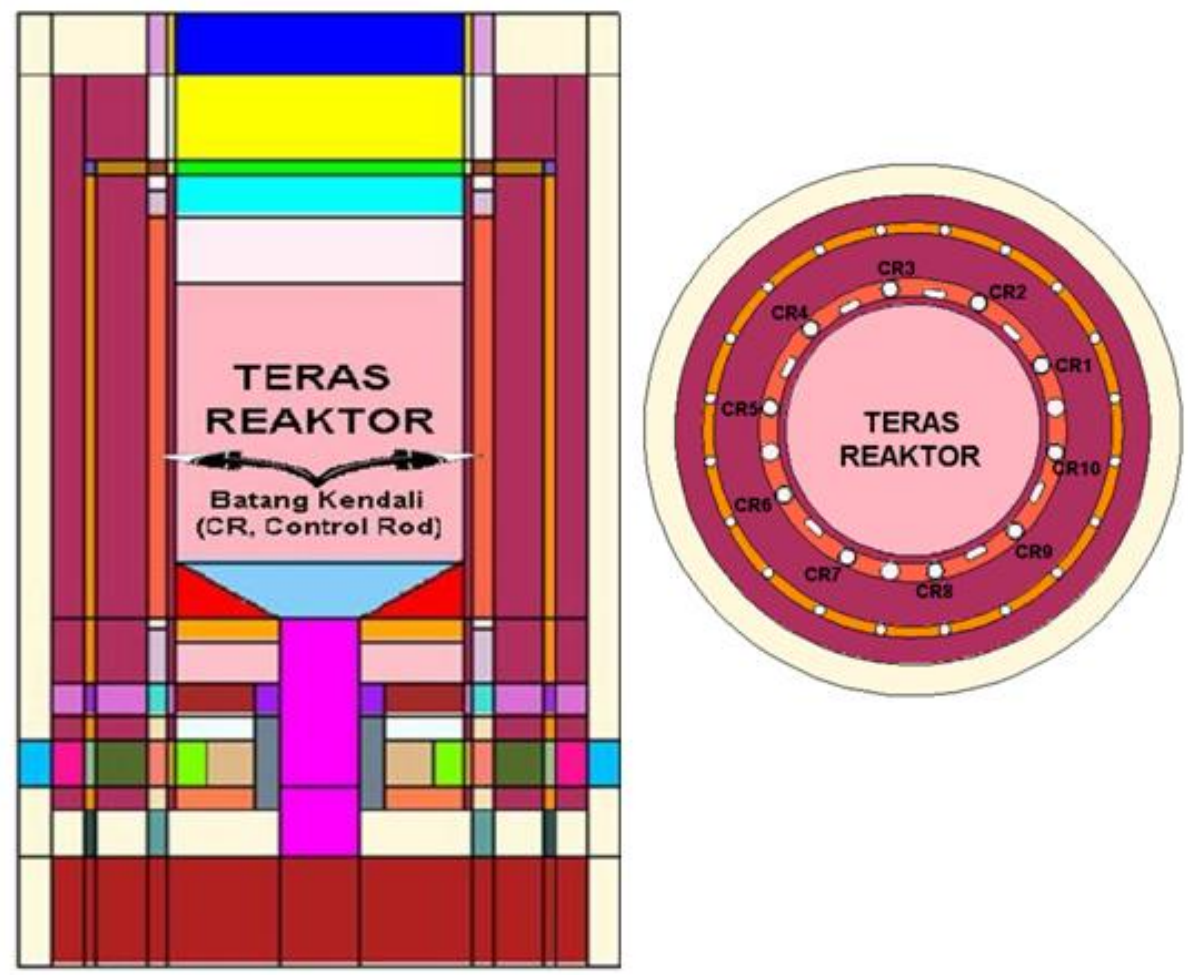

Gambar 3. Model vertikal dan horizontal Benchmark teras HTR-10 dengan MCNP6.

\section{HASIL PERHITUNGAN DAN DISKUSI}

Identifikasi perhitungan Benchmark reaktivitas batang kendali HTR-10 meliputi perhitungan reaktivitas batang kendali teras penuh (problema Benchmark B3) dan perhitungan reaktivitas batang kendali teras inisial (problema Benchmark B4). Masing-masing problema diklasifikasikan ke dalam dua kelompok, yaitu problema Benchmark reaktivitas sepuluh batang kendali terinsersi penuh (fully in) dan problema Benchmark reaktivitas satu batang kendali terinsersi penuh (fully in) sedangkan lainnya dalam posisi ditarik penuh (fully out). Teras penuh didefinisikan sebagai teras yang dimuati sekumpulan pebble dengan volume nominal $5 \mathrm{~m}^{3}$ atau ketinggian teras $197 \mathrm{~cm}$ sedangkan teras inisial didefinisikan sebagai teras dengan tumpukan pebble yang mengisi teras dengan ketinggian $126 \mathrm{~cm}$. Tabel 5 meringkas problema Benchmark reaktivitas batang kendali HTR-10.

Tabel 5. Problema Benchmark reaktivitas batang kendali HTR-10.

\begin{tabular}{lll}
\hline \multirow{2}{*}{ Problema B3 (teras penuh) } & B3.1 & Sepuluh batang kendali fully in \\
\cline { 2 - 3 } & B3.2 & Satu batang kendali fully in, lainnya fully out \\
\hline Problema B4 (teras inisial) & B4.1 & Sepuluh batang kendali fully in \\
\cline { 2 - 3 } & B4.2 & Satu batang kendali fully in, lainnya fully out \\
\hline
\end{tabular}

Perhitungan Benchmark reaktivitas batang kendali $\left(\rho_{w}\right)$ HTR-10 dikerjakan dalam kondisi atmosfir helium dan temperatur $20^{\circ} \mathrm{C}$ mengikuti persamaan: $\rho_{w}=\left[K_{\text {eff }, 1}-K_{\text {eff }, 2}\right] /\left[K_{\text {eff }, 1} \times K_{\text {eff }, 2}\right]$ dengan $K_{e f f, 1}$ dan $K_{e f f, 2}$ masing-masing merepresentasikan nilai faktor multiplikasi reaktor ( $K_{\text {eff }}$ ) ketika batang 
kendali terinsersi penuh (fully in) dan ketika batang kendali dalam posisi ditarik penuh (fully out). Konsentrasi isotopik partikel TRISO serta matriks grafit dan shell grafit yang identik, yang digunakan dalam seluruh perhitungan, diberikan dalam Tabel 6 dan 7. Konsentrasi reflektor grafit dan seluruh region HTR-10 diadopsi dari IAEA-TECDOC-1382 [10].

Tabel 6. Konsentrasi isotopik (atom/barn-cm) partikel TRISO dalam bahan bakar pebble [6].

\begin{tabular}{ccccc}
\hline \multicolumn{5}{c}{ Kernel UO2 } \\
\hline$U^{235}$ & $\mathrm{U}^{238}$ & $\mathrm{O}^{16}$ & $\mathrm{~B}^{10}$ & $\mathrm{~B}^{11}$ \\
\hline $3.99207 \times 10^{-3}$ & $1,92445 \times 10^{-2}$ & $4,64733 \times 10^{-2}$ & $1,84964 \times 10^{-8}$ & $7,44502 \times 10^{-8}$ \\
\hline \multicolumn{5}{c}{ Lapisan coating } \\
\hline Buffer & $5,51518 \times 10^{-2}$ & $\mathrm{Si}^{28}$ & $\mathrm{Si}^{29}$ & $\mathrm{Si}^{30}$ \\
IPyC & $9,52621 \times 10^{-2}$ & 0 & 0 & 0 \\
SiC & $4,77240 \times 10^{-2}$ & $4,39872 \times 10^{-2}$ & $2,24780 \times 10^{-3}$ & $1,48899 \times 10^{-3}$ \\
oPyC & $9,52621 \times 10^{-2}$ & 0 & 0 & 0 \\
\hline
\end{tabular}

Tabel 7. Konsentrasi isotopik (atom/barn-cm) matriks grafit dan shell grafit [6].

\begin{tabular}{ccc}
\hline & Matriks grafit & \\
\hline$C^{12}$ & $B^{10}$ & $B^{11}$ \\
$8,67417 \times 10^{-2}$ & $2,24401 \times 10^{-8}$ & $9,03242 \times 10^{-8}$ \\
\hline & Shell grafit & \\
\hline$C^{12}$ & $B^{10}$ & $B^{11}$ \\
$8,67417 \times 10^{-2}$ & $2,24401 \times 10^{-8}$ & $9,03242 \times 10^{-8}$ \\
\hline
\end{tabular}

Untuk menentukan reaktivitas batang kendali teras penuh dan teras inisial, perhitungan faktor multiplikasi reaktor $\left(K_{\text {eff }}\right)$ diselesaikan dengan mengatur posisi batang kendali. Dalam kondisi yang sebenarnya, karakteristik moderator pebble yang dimuatkan dalam teras inisial dan teras penuh berbeda dengan yang didefinisikan dalam Benchmark original. Moderator pebble yang disiapkan untuk kritikalitas pertama mempunyai densitas $1,84 \mathrm{~g} / \mathrm{cm}^{3}$, lebih besar dari nilai yang ditetapkan dalam Benchmark original $\left(1,73 \mathrm{~g} / \mathrm{cm}^{3}\right)$ dan impuritas boron ekuivalen 0,125 ppm (bukan 1,3 ppm). Eksperimen kritikalitas pertama dibuat dalam kondisi atmosfir udara, bukan helium seperti yang diindikasikan dalam Benchmark original.

Dalam studi ini, seluruh perhitungan didasarkan pada kondisi aktual. Perhitungan $K_{\text {eff }}$ dikerjakan dengan pustaka data nuklir ENDF/B-VII pada temperatur teras $27^{\circ} \mathrm{C}$, bukan $20{ }^{\circ} \mathrm{C}$ seperti yang ditentukan dalam Benchmark. Dengan opsi TMP card yang disediakan MCNP6 perbedaan ini dapat dikoreksi namun untuk temperatur yang rendah opsi ini tidak banyak memberikan pengaruh yang signifikan. Sebanyak 210 siklus dengan 5000 sumber neutron per siklus dan skipping 10 siklus disimulasikan dalam seluruh perhitungan. Skipping digunakan untuk menghindari konvergensi sumber.

Beberapa negara yang berpartisipasi dalam problema Benchmark reaktivitas batang kendali menggunakan program perhitungan fisika teras yang bervariasi dari kombinasi model transport dan difusi neutron hingga model Monte Carlo yang detail. China memanfaatkan program VSOP dengan pustaka GAM dan THERMOS yang diekstraksi dari basis data nuklir ENDF/B-V dan JEF-1. Jerman menggunakan perangkat lunak yang sama seperti China dalam model difusi teras. Simulasi Monte Carlo dikerjakan China dengan MCNP-4A dan data nuklir ENDF/B-V, Perancis dengan TRIPOLI4 menggunakan simplifikasi dan revisi model pebble bed serta Kuba dengan MCNPX dan pustaka ENDF/B-VII.

Tabel 8 dan 9 merangkum hasil perhitungan Benchmark reaktivitas batang kendali teras penuh (problema B3) dan teras inisial (problema B4). Kedua tabel mengkonfirmasi prediksi MCNP6 memiliki kesesuaian yang cukup baik dengan pendekatan difusi maupun model Monte Carlo yang diestimasi China [10]. Bias MCNP6 sebesar 2,28 \% dan 3,40 \% (problema B3.1) serta 6,44 \% dan 0,33 \% (problema B4.1) diberikan masing-masing untuk perhitungan reaktivitas sepuluh batang kendali fully in. 
Jurnal Iptek Nuklir Ganendra

Ganendra Journal of Nuclear Science and Technology

Vol. 9, No. 2, Juli 2016: 95-103

\begin{tabular}{|c|c|c|c|c|c|c|}
\hline \multicolumn{2}{|c|}{ Problema Benchmark } & Chinaa & Perancis & Jermanb & Kubac & Studi inid \\
\hline \multirow[b]{2}{*}{ B3.1 } & $\begin{array}{l}\text { Perhtungan Difusi / } \\
\text { Transport }\end{array}$ & 14,46 & - & 15,73 & - & - \\
\hline & $\begin{array}{l}\text { Perhitungan Monte } \\
\text { Carlo }\end{array}$ & 15,31 & $\begin{array}{l}13,06^{\mathrm{e}} \\
13,44^{f}\end{array}$ & - & 14,18 & 14,79 \\
\hline \multirow{2}{*}{ B3.2 } & $\begin{array}{l}\text { Perhtungan Difusi / } \\
\text { Transport }\end{array}$ & 1,277 & - & 1,48 & - & - \\
\hline & $\begin{array}{l}\text { Perhitungan Monte } \\
\text { Carlo }\end{array}$ & 1,343 & $\begin{array}{l}1,35^{\mathrm{e}} \\
1,31^{f}\end{array}$ & - & 1,53 & 1,07 \\
\hline
\end{tabular}

avSOP, bVSOP, CMCNPX dan ENDF/B-VII, dMCNP6 dan ENDF/B-VII, eTRIPOLI4 dengan simplifikasi model pebble bed, ${ }^{\mathrm{f}} \mathrm{TRIPOL} / 4$ dengan revisi model pebble bed

Tabel 9. Hasil perhitungan reaktivitas batang kendali (\%) teras inisial (problema Benchmark B4).

\begin{tabular}{|c|c|c|c|c|c|c|}
\hline \multicolumn{2}{|c|}{ Problema Benchmark } & China ${ }^{a}$ & Perancis & Jermanb & Kubac & Studi inid \\
\hline \multirow[b]{2}{*}{ B4.1 } & $\begin{array}{l}\text { Perhtungan Difusi I } \\
\text { Transport }\end{array}$ & 17,23 & - & 19,31 & - & - \\
\hline & $\begin{array}{l}\text { Perhitungan Monte } \\
\text { Carlo }\end{array}$ & 18,28 & $\begin{array}{l}13,66^{\mathrm{e}} \\
13,80^{\mathrm{f}}\end{array}$ & - & 16,58 & 18,34 \\
\hline \multirow[b]{2}{*}{ B4.2 } & $\begin{array}{l}\text { Perhtungan Difusi / } \\
\text { Transport }\end{array}$ & 1,540 & - & 1,86 & - & - \\
\hline & $\begin{array}{l}\text { Perhitungan Monte } \\
\text { Carlo }\end{array}$ & 1,572 & $1,52^{\mathrm{e}}$ & - & 1,65 & 1,51 \\
\hline
\end{tabular}

aVSOP, bVSOP, CMCNPX dan ENDF/B-VII, dMCNP6 dan ENDF/B-VII, eTRIPOLI4 dengan simplifikasi model pebble bed, ${ }^{\mathrm{f}} \mathrm{TRIPOL} / 4$ dengan revisi model pebble bed

Jika diyakini hasil China yang paling tepat, dalam kasus reaktivitas satu batang kendali fully in di teras penuh (problema B3.2), simulasi MCNP6 memperlihatkan hasil yang kurang menguntungkan dibandingkan TRIPOLI4. Walaupun demikian, jika data eksperimen Benchmark reaktivitas setiap batang kendali HTR-10 dalam teras penuh tersedia, mungkin hasil ini bukan yang terburuk bahkan justru bisa menjadi sebaliknya. Di teras inisial (problema B4.2), bersama TRIPOLI4 model MCNP6 mendemonstrasikan akurasinya yang paling tinggi dengan bias perhitungan $1,95 \%$ dibandingkan VSOP dan 3,94 \% dibandingkan MCNP-4A. Perbedaan perhitungan teori difusi dan Monte Carlo secara teoretik dapat disebabkan oleh pendekatan model geometri reaktor yang dibuat dan struktur energi tampang lintang data nuklir yang digunakan.

Eksperimen kalibrasi batang kendali dikerjakan ketika ketinggian teras reaktor $123,86 \mathrm{~cm}$. Kondisi eksperimen ini berbeda dengan yang didefinisikan dalam problema Benchmark. Ketinggian teras inisial dalam problema B4.2 adalah $126 \mathrm{~cm}$ [10]. Kondisi lainnya yang berbeda adalah dalam problema Benchmark batang kendali tipikal (CR3) ditarik ke atas dari posisi terinsersi penuh (fully in) atau $0 \mathrm{~cm}$ hingga posisi ditarik penuh (fully out) atau $275 \mathrm{~cm}$ sedangkan dalam eksperimen dari $52 \mathrm{~cm}$ hingga $275 \mathrm{~cm}$. Itulah sebabnya mengapa hasil perhitungan reaktivitas batang kendali dengan MCNP6 (1,51 \%) berbeda 2,70 \% dengan eksperimen $(1,4693 \%)$. Posisi batang kendali fully in dan fully out dalam eksperimen dan problema Benchmark seharusnya dibuat sama untuk memperoleh komparasi yang lebih baik.

\section{KESIMPULAN}

Studi model Benchmark dalam perhitungan reaktivitas batang kendali HTR-10 telah dilakukan dengan memanfaatkan program transport Monte Carlo MCNP6 dan pustaka data nuklir energi kontinu ENDF/B-VII. Prediksi MCNP6 memiliki kesesuaian yang cukup baik dengan pendekatan difusi maupun model Monte Carlo 
yang diestimasi China untuk perhitungan reaktivitas sepuluh batang kendali fully in di teras penuh, masingmasing dengan bias perhitungan 2,28 \% dan 3,40 \% (problema Benchmark B3.1) serta 6,44\% dan 0,33\% (problema Benchmark B4.1). Simulasi MCNP6 memperlihatkan hasil yang kurang menguntungkan dalam kasus reaktivitas satu batang kendali fully in di teras penuh (problema Benchmark B3.2), namun sebaliknya mendemonstrasikan akurasinya yang paling tinggi di teras inisial dengan bias eksperimen 2,70 \% (problema Benchmark B4.2). Hasil-hasil ini menyimpulkan bahwa model Benchmark MCNP6 yang digunakan dalam perhitungan reaktivitas batang kendali HTR-10 dapat diaplikasikan untuk analisis fisika teras reaktor pebble bed lainnya.

\section{UCAPAN TERIMAKASIH}

Ucapan terimakasih kami sampaikan kepada Kepala PTKRN, Dr. Geni Rina Sunaryo, M.Sc., yang memberikan motivasi dan dukungan dalam riset ini. Ucapan terimakasih kami sampaikan pula kepada Prof. Surian Pinem, M.Si. atas diskusi dan sarannya yang berharga untuk perbaikan makalah ini.

\section{DAFTAR PUSTAKA}

1. J. Rosales, et al., "Computational Model for the Neutronic Simulation of Pebble Bed Reactor's Core Using MCNPX", International Journal of Nuclear Energy, Volume 2014, Article ID 279073, http://dx.doi.org/10.1155/2014/279073 (2014)

2. H. Chang, et al., "Analysis of HTR-10 First Criticality with Monte Carlo Code Tripoli-4.3", The 2nd International Topical Meeting on High Temperature Reactor Technology, Beijing, China (2004), \#Paper C11: $1-10$

3. J.T. Goorley, et al., "Initial MCNP6 Release Overview - MCNP6 version 1.0", LA-UR-13-22934, Los Alamos National Laboratory (2013)

4. M.B. Chadwick, et al., "ENDF/B-VII: Next Generation Evaluated Nuclear Data Library for Nuclear Science and Technology", Nuclear Data Sheets, 107 (2006): 2931-3060,

5. J. P. Curbelo, et al., "Random Detailed Model for Probabilistic Neutronic Calculation in Test Reactor HTR10", Computational Modeling Meeting XVII, Science and Technology of Materials Meeting V, Catholic University of Petrópolis (UCP), Petrópolis RJ, Brasil, (2014)

6. Zuhair, Suwoto, Piping Supriatna, "Studi Model Heksagonal MCNP5 dalam Perhitungan Benchmark Fisika Teras HTR-10", Jurnal Matematika \& Sains, 17.2 (2012): 61-70

7. L. Halla-aho, "Development of an HTR-10 Model in the Serpent Reactor Physics Code", Lappeenranta University of Technology, Faculty of Technology, Degree Programme in Energy Technology, (2014)

8. Meng-Jen Wang, et al., "Criticality Calculations of the HTR-10 Pebble-bed Reactor with SCALE6/CSAS6 and MCNP5", Annals of Nuclear Energy, Volume 64, (2014): 1-7

9. W. K. Terry, et al., "Evaluation of the HTR-10 Reactor as Benchmark for Physics Code QA", PHYSOR-2006, ANS Topical Meeting on Reactor Physics (2006)

10. IAEA-TECDOC-1382, "Evaluation of High Temperature Gas-Cooled Reactor Performance: Beenchmark Analysis Related to Initial Testing of the HTTR and HTR-10", IAEA, Vienna, Austria (2003).

11. Zuhair, Suwoto, "Analisis Efek Kecelakaan Water Ingress terhadap Reaktivitas Doppler Teras RGTT200K", Jurnal Teknologi Reaktor Nuklir TRI DASA MEGA, 17.1(2015): 31-40

12. Zuhair, Suwoto, Putranto Ilham Yazid, "Investigasi Parameter Bahan Bakar Pebble dalam Perhitungan Teras Thorium RGTT200K", Jurnal Sains dan Teknologi Nuklir Indonesia, 14.2 (2013): 65-78 